\title{
Cognitive biases influence clinical medicine practice
}

\section{Piryani Rano Mal1, Piryani Suneel2, Piryani Rajesh3}

1Rano Mal Piryani, Professor and Head of Department of Internal Medicine, Universal College of Medical Sciences, Nepal (Fellowship in Medical Education) 2Suneel Piryani- MPH \&MPhil (Public Health Consultant, Karachi Pakistan)

3Rajesh Piryani- PhD (South Asian University, Delhi, India)

INTRODUCTION

I. Biases in clinical medicine practice decision making in clinical practice influenced by different biases; among them cognitive and affective biases are important one. Both

\begin{abstract}
Cognitive biases are prevalent in the clinical practice and recognized cause of medical error. Error due to cognitive biases influences decision-making process of healthcare professionals. The causes of cognitive biases are varied. Clinician must understand the causes of cognitive biases and acknowledge the biases happening in clinical practice. Awareness of potential biases may help clinician improve patients' care and minimize medico-legal risks. Machine learning applications have been tried for the avoidance of biases occurring in health professionals' diagnostic and therapeutic decision-making process but machine learning algorithms may also be subject to biases. Machine learning research in this aspect continues. Clinicians must learn how to minimize the cognitive biases and take pragmatic approach and follow the good decision-making rules.
\end{abstract}

Key words: Cognitive biases, clinical practices, Medico-legal aspects

A bias is a tendency, inclination, or prejudice toward or against something or someone [1]. Bias is the psychological tendency to make a decision based on incomplete information and subjective factors rather than empirical evidence [2]. Clinicians may have conscious or unconscious biases affecting patients' care; more often clinician biases are unconscious [3].

\section{Biases influencing decision making and diagnosis in clinical practice}

Clinician must know and understand the biases occurring in clinical practice; awareness of potential biases can facilitate clinician improve patients' care and minimize medico legal risks [3]. The diagnosis and have profound impact on patients' care [3].

This article briefly focuses on cognitive biases.

\section{Cognitive Biases}

It is reported that cognitive bias accounts for $70 \%$ of diagnostic errors [4] and diagnostic errors are associated with $6-17 \%$ of adverse events in hospitals [5]. Cognitive biases are various unconscious influences, short cuts and behaviors which influence ones decisionmaking process [6]. 
Table 1a: Some of the important cognitive biases documented in literature [2, 7]

\begin{tabular}{|c|c|c|}
\hline Bias Name & Definition & Example \\
\hline Anchoring $^{7}$ & $\begin{array}{l}\text { Hastily giving undue importance to } \\
\text { initial clinical findings, facts or } \\
\text { characteristics, }\end{array}$ & $\begin{array}{l}\text { The clinician assumes that mental status } \\
\text { changes in a disheveled, malodorous } \\
\text { patient are due to psychiatric conditions } \\
\text { rather than diabetic ketoacidosis. }\end{array}$ \\
\hline Availability $^{7}$ & $\begin{array}{l}\text { Formulating a diagnosis based on how } \\
\text { easily it comes to one's mind, rather } \\
\text { than its clinical likelihood, }\end{array}$ & $\begin{array}{l}\text { After a publicized settlement for a missed } \\
\text { pulmonary embolism, patients with } \\
\text { symptoms atypical of embolism are } \\
\text { worked up for this condition in the local } \\
\text { emergency department. }\end{array}$ \\
\hline Base rate neglect ${ }^{2}$ & $\begin{array}{l}\text { This happens when the underlying } \\
\text { incidence rates of conditions or } \\
\text { population-based knowledge are } \\
\text { overlooked as if they do not apply to the } \\
\text { patient in question. }\end{array}$ & $\begin{array}{l}\text { A positive exercise stress test in a young } \\
\text { woman prompting an angiogram. The } \\
\text { 'base rate' is so low in this population that } \\
\text { this result is more likely false positive } \\
\text { than true positive. }\end{array}$ \\
\hline Conjunction rule ${ }^{2}$ & $\begin{array}{l}\text { This rule is an incorrect belief that the } \\
\text { probability of multiple events being true } \\
\text { is greater than a single event. }\end{array}$ & $\begin{array}{l}\text { A confused patient with hypoxia and } \\
\text { deranged renal function is far more likely } \\
\text { to simply have a pneumonia than a } \\
\text { subdural/pulmonary embolism/ } \\
\text { obstruction simultaneously. }\end{array}$ \\
\hline Commission $^{7}$ & $\begin{array}{l}\text { The predisposition in the midst of } \\
\text { uncertainty to err on the side of action, } \\
\text { irrespective of the evidence. }\end{array}$ & $\begin{array}{l}\text { Despite evidence advising against pain } \\
\text { medication for simple lumbar strain, } \\
\text { physicians continue to prescribe opioid } \\
\text { analgesics. }\end{array}$ \\
\hline Confirmation $^{7}$ & $\begin{array}{l}\text { Giving preference to the clinical findings } \\
\text { that confirm a diagnosis (for example } \\
\text { concentrating on history characteristics } \\
\text { that reinforces the clinician's pre- } \\
\text { existing view about a diagnosis) }\end{array}$ & $\begin{array}{l}\text { When a patient with a history of drug- } \\
\text { seeking is seen for lower back pain, the } \\
\text { clinician focuses on the patient's apparent } \\
\text { lack of discomfort and minimizes his } \\
\text { complaint of bowel dysfunction and lower } \\
\text { extremity weakness. }\end{array}$ \\
\hline
\end{tabular}

Cognitive biases are also known as 'heuristics'. Heuristics can be mental shortcuts such as using trial and error, a rule of thumb or an educated guess that ease the cognitive load of making a decision [7].

Some of the important cognitive biases documented in the literature are mentioned in Table-1a and $1 \mathrm{~b}$. Clinician may encounter other important biases on day today. All these biases may interfere to reach correct diagnosis or prescribe suitable and appropriate treatment for the patients. More than one bias may affect the diagnosis or management of a patient as biases may also be inter-related [3].

O'Sullivan ED, Schofield SJ suggested that clinicians have to learn how to minimize the cognitive biases. They have to improve their 
Table 1b: Some of the important cognitive biases documented in the literature [2, 7]

\begin{tabular}{|c|c|c|}
\hline Diagnostic $^{7}$ momentum & $\begin{array}{l}\text { The tendency of clinicians to agree on a } \\
\text { diagnosis without probing its validity or } \\
\text { reviewing the initial decision-making } \\
\text { process }\end{array}$ & $\begin{array}{l}\text { A patient whose medical record lists a } \\
\text { diagnosis of “dementia” transfers to a new } \\
\text { physician. The patient exhibits symptoms } \\
\text { atypical of dementia; yet, the correct } \\
\text { diagnosis, neurosyphilis, is not explored. }\end{array}$ \\
\hline Framing effect ${ }^{7}$ & $\begin{array}{l}\text { Collecting only features that support a } \\
\text { diagnosis (analogous to confirmation } \\
\text { bias) }\end{array}$ & $\begin{array}{l}\text { With a patient believed to be malingering, } \\
\text { his history of psychiatric illness is } \\
\text { emphasized during a presentation to the } \\
\text { attending physician. }\end{array}$ \\
\hline Gambler's fallacy $^{7}$ & $\begin{array}{l}\text { The pretest probability of a diagnosis } \\
\text { might be influenced by preceding-but } \\
\text { independent - events. }\end{array}$ & $\begin{array}{l}\text { Because the last } 5 \text { patients seen in the } \\
\text { emergency department had non-cardiac } \\
\text { chest pain, the next one with chest pain is } \\
\text { more likely to be thought to have a serious } \\
\text { cardiac condition. }\end{array}$ \\
\hline Omission $^{7}$ & $\begin{array}{l}\text { The natural progression of a disease as } \\
\text { per natural history of disease is more } \\
\text { acceptable to clinician as an explanation } \\
\text { for a patient's outcome rather than } \\
\text { actions attributed to the clinician. }\end{array}$ & $\begin{array}{l}\text { During cardiac resuscitation, chest } \\
\text { compressions are not performed to the } \\
\text { proper depth so as to avoid causing rib } \\
\text { fractures, thereby possibly rendering the } \\
\text { procedure ineffective. }\end{array}$ \\
\hline Overconfidence $^{2}$ & $\begin{array}{l}\text { An inflated view of diagnostic ability of } \\
\text { clinician leading to subsequent error. } \\
\text { The confidence in his/her judgement } \\
\text { does not match with the accuracy of the } \\
\text { judgement }\end{array}$ & $\begin{array}{l}\text { A doctor trusting their assessment more } \\
\text { than they should particularly problematic } \\
\text { with inaccurate examinations, such as } \\
\text { auscultation for pneumonia }\end{array}$ \\
\hline Representativeness $^{2}$ & $\begin{array}{l}\text { Misinterpreting the likelihood of an } \\
\text { event bearing in mind both the key } \\
\text { resemblances to its parent population, } \\
\text { and the individual features that define } \\
\text { that event }\end{array}$ & $\begin{array}{l}\text { A man with classic symptoms of a heart } \\
\text { attack, but also anxious, and who's breath } \\
\text { smelled of alcohol. The latter details have } \\
\text { no bearing on the likelihood of a heart } \\
\text { attack, nor alter the degree to which he is a } \\
\text { member of his risk demographic but } \\
\text { distract and decrease the diagnostic pick } \\
\text { up. }\end{array}$ \\
\hline Search satisfying $^{2}$ & $\begin{array}{l}\text { Stopping to look for further information } \\
\text { or any alternate explanation when the } \\
\text { first reasonable solution is found. }\end{array}$ & $\begin{array}{l}\text { When encountering an acutely dyspneic } \\
\text { patient, treating their obvious pneumonia } \\
\text { and stopping investigations at that point, } \\
\text { failing to search for and recognize the } \\
\text { secondary myocardial infarction }\end{array}$ \\
\hline
\end{tabular}

understanding and awareness of their own biases and take pragmatic approach and follow good decision-making rules [7]. Khadilkar SV and Khadilkar SS suggested 
three steps to avoid bias: 1) Increasing awareness of biases and providing facts, 2) Helping improve reasoning, promote freethinking and enhance decision-making skills and 3) Making working conditions more conducive and develop ability of health professionals to take unbiased decisions [8].

Machine learning (ML) has also been tried in healthcare for the avoidance of biases observed in health professionals' diagnostic or therapeutic decision-making process. ML algorithms, however, may also be subject to biases. It is promising that ML applications will certainly help in reducing the stress of the healthcare professionals and improving the quality of healthcare systems in days to come [9].

\section{CONCLUSION}

However, ML will likely revolutionize clinical decision-making process in future, but healthcare professionals have to develop their capacity for understanding main cognitive biases; appreciate how they could interfere with their diagnostic reasoning and enhances their decision-making processto be unbiased and objective oriented.

\section{ACKNOWLEDGEMENTS}

Authors acknowledge all authors whose articles are used for the reference in this article. Authors appreciates principal author Thomas Yuen of article "Cognitive bias: Its influence on clinical diagnosis" for granting permission to principal author of this article for using examples of biases. Authors also indebted to principal author ED O'Sullivan who permitted to use examples of biases mentioned in article "Cognitive bias in clinical medicine".

\section{REFERENCES}

1. Bias I Psychology Today International Available at: https://www.psychologytoday.com/intl/basic s/bias Accessed on December 15, 2019

2. Yuen T Derenge D, Kalman N. Cognitive bias: Its influence on clinical diagnosis. The Journal of Family Practice 2018; 67(6): 366;372

3. Overcoming bias in medical practice. https:// www.cmpa-acpm.ca/en/advice-publications / browse-articles/2012/overcoming-bias-inmedical-practice Accessed on December 15, 2019

4. Saber Tehrani AS, Lee H, Mathews SC, Shore A, Makary MA, Pronovost PJ, Newman-Toker DE. Twenty five-year summary of US malpractice claims for diagnostic errors 1986-2010: an analysis from the National Practitioner Data Bank. BMJ QualSaf. 2013;22(8):672-80. https://doi.org/10.1136/bmjqs-2012001550

5. Balogh EP, Miller BT, Ball JR. Improving diagnosis in health care. Washington: National Academic Press; 2015.

6. Ludolph R and Schulz PJ, Debiasing HealthRelated Judgements and Decision Making: A systematic review. Medical Decision Making, 2017. 38(1): 3-13.

7. ED O'Sullivan, SJ Schofield. Cognitive bias in clinical medicine. J R Coll Physicians Edinb 2018; 48: 225-232 | doi: 10.4997/JRCPE.2018.306

8. Khadilkar SV and Khadilkar SS. Bias in Clinical Practice. The Journal of Obstetrics and Gynecology of India (January-February 2020) 70(1):1-5 https://doi.org/10.1007/s13224019-01304-5

9. Gianfrancesco MA, Tamang S, Yazdany J, Schmajuk G. Potential Biases in Machine Learning Algorithms Using Electronic Health Record Data. JAMA Intern Med. November 2018; $\quad 178(11)$ : 1544-1547. doi:10.1001/jamainternmed.2018.3763.

\section{Correspondence to:}

\section{DR. RANO MAL PIRYANI}

Professor and Head of Department of Internal Medicine Chief Coordinator- Health Professions Training Committee Universal College of Medical Sciences, Bhairahawa, Nepal Email: rano.piryani@gmail.com, $\underline{\text { r piryani@hotmail.com }}$ Cell No: 00977-9841269522 